\title{
Maximising Incidental Vocabulary Acquisition in Spanish as a Foreign Language
}

\author{
Maria Pilar Agustín-Llach \\ Departamento de Filologías Modernas, Universidad de La Rioja \\ Email: maria-del-pilar.agustin@unirioja.es
}

Received 30 October 2014; accepted 18 June 2015; published 24 June 2015

Copyright (C) 2015 by author and Scientific Research Publishing Inc.

This work is licensed under the Creative Commons Attribution International License (CC BY).

http://creativecommons.org/licenses/by/4.0/

(c) (i) Open Access

\begin{abstract}
This paper presents a study designed to contribute some evidence for incidental vocabulary acquisition in the foreign language. Finding the most effective approach to vocabulary learning and teaching has occupied researchers intensively. This is a small scale study in which the lexical learning of 52 Italian learners of Spanish as a foreign language is tested. Learners are submitted to three conditions with different requirements (output vs. input, multiple exposures vs. target word usage, meaning comparison and selection vs. message production), but in all three, vocabulary is learned in an incidental way and with a lexical learning condition present in the task. Results point to lack of statistical differences in lexical gains among the three interventions. From this finding, it might be assumed that it is not the nature of the manipulation, input or output, multiple exposures, or target word usage, but complying with any condition for lexical learning that plays a determining role in lexical acquisition.
\end{abstract}

\section{Keywords}

Incidental Vocabulary Acquisition, Output Tasks, Input Tasks, Amount of Exposure

\section{Introduction}

Myriad studies have dealt with the issue of foreign language (FL) vocabulary acquisition and teaching since the second half of the last century. Research findings so far, however, have not fulfilled the curiosity of researchers to learn more about foreign vocabulary acquisition, or the endeavour of teachers to improve vocabulary teaching.

The dichotomy between incidental and intentional learning/teaching has pervaded in the last years (e.g. Meara, 
1997; Nagy, 1997; Sökmen, 1997; Singleton, 1999; de Groot, 2000; Nation, 2001, and in L1 acquisition McKeown \& Curtis, 1987). This distinction is very useful in discussions on how to best and most cost-effectively introduce new words in the FL classroom.

Intentional vocabulary learning ${ }^{1}$ is very effective in relative terms (e.g. Gu, 2003, Lee, 2003), but it is very time consuming and we cannot possibly teach every word in the FL. Additionally, there is practical evidence that some words are learned without having been taught explicitly, as we all know from our own experience as FL learners (Cf. Criado Sánchez et al., 2010). Hence, incidental vocabulary acquisition seems to be playing an outstanding role. The main difference between incidental and intentional lexical learning is the features of the input they pay attention to: meaning in incidental, and form in intentional learning (Nation, 2001: p. 2). So far, there is no conclusive evidence about which vocabulary learning approach is more effective, and research studies offer non-definite or contradictory results (Gass et al., 1999; Rodríguez \& Sadoski, 2000; Gu, 2003; Laufer, 2003; or Pressley et al., 1987 for L1).

Particularly, in this paper we are concerned with incidental vocabulary learning. The learning of vocabulary as a by-product of other activities such as reading or essay writing has generated much interest and many researchers address this issue (for reading and vocabulary see e.g. Pitts, White, \& Krashen, 1989; Dupuy \& Krashen, 1993; Cho \& Krashen, 1994; Grabe \& Stoller, 1997; Mason \& Krashen, 1997; Horst et al., 1998; Lao \& Krashen, 2000; Zahar, Cobb, \& Spada, 2001; Rodrigo, Krashen, \& Gribbons, 2004, for writing and vocabulary see e.g. Cameron, 2001; Katznelson, Perpignan, \& Rubin, 2001; Harklau, 2002; Muncie, 2002, Lee, 2003).

\section{Incidental Vocabulary Learning}

As briefly hinted above, incidental vocabulary acquisition is generally understood ${ }^{2}$ to refer to the vocabulary incorporated as the result of accomplishing another activity not aimed at vocabulary teaching/learning, specifically. Different theories or theoretical strands have dealt with this issue. Here, the focus will be on two of them: 1) input hypothesis, and 2) output hypothesis.

It seems to be a well-grounded statement that lexical development in the mother tongue happens as a result of massive exposure to "comprehensible input”" (Krashen, 1989; Horst, Cobb, \& Meara, 1998; Gardner, 2004). For L2 vocabulary acquisition, the input hypothesis, or non-instruction trend, states that when the learner encounters a new word while reading or performing another communicative activity, he or she will guess its meaning. The learner might make a right or wrong guess, and might totally or partially remember the meaning of the new word, or not at all. As the learner gets repeatedly exposed to this word, meaning retention will improve and information about the word will be expanded (Laufer, 2004). Hence, this theory assumes that a learner who is regularly exposed to the FL will notably improve the size and depth of his/her lexical repertoire (Krashen, 1989).

Reading, especially extensive reading for pleasure, is assumed to be the most favourable condition for vocabulary learning (see esp. Krashen, 1989). In fact, Krashen (1989) and other advocates of the input hypothesis (Zahar, Cobb, \& Spada, 2001; Rodrigo, Krashen, \& Gribbons, 2004) believe that reading only can lead to satisfactory levels of vocabulary development. Generally considered, this seems to be true. However, the amount of reading hours, or broadly speaking, of exposure to the FL necessary for the development of lexical competence goes beyond what seems reasonable for learners in FL situations (Horst et al., 1998; de Groot, 2000; Zahar et al., 2001). Hence, some extra active engagement is desirable to maximize incidental vocabulary acquisition (Jiang, 2004, Rott, 2004, Laufer \& Hulstijn, 2001, Nation, 2001, Gu, 2003). In her studies, Rott (e.g. 2004) proposed some form of enhanced reading or reading followed by production activities aimed at increasing the effectiveness of the reading task (see also Criado Sánchez et al., 2010).

As a reaction to the input hypothesis and its statement that exposure to "comprehensible input" is a sufficient condition to learn the FL, Swain (1985) formulated the "output hypothesis" or "comprehensible output hypothesis". The output hypothesis claims that producing language, under some circumstances, contributes to the proc-

\footnotetext{
${ }^{1}$ Multiple choice, synonym, antonym or hyperonym matching, collocations, translation, bilingual lists, mnemonic techniques or word form analysis are typical activities for intentional vocabulary acquisition.

${ }^{2}$ This is not, nevertheless, the only definition of incidental vocabulary acquisition. There is much disquisition about the concept, some of which is collected in Rieder (2000).

${ }^{3}$ Term coined by Krashen (1989) to refer to the difficulty degree of the language samples learners are exposed to. In order for input to become intake, that is, in order for language to be learned, it has to be comprehensible, that is understandable, but it needs to include some new elements to the learner. As vocabulary is concerned, comprehensible input refers to a sample with little unknown words immersed in a context of known words.
} 
ess of second language acquisition (SLA). Being forced or pushed to produce in the second language (L2), the learner might realize the language problems, or the gap between the intended message and the means to express it. As a consequence, the learner engages in a linguistic search process and endeavours to find the correct solution to the language problem. Thus, attention is drawn to relevant input to foster new learning (cf. Swain, 1985). In this sense, speaking or writing in the L2 creates new linguistic knowledge or contributes to consolidating existing one. The input and output hypotheses complement each other.

Studies trying to test the effectiveness of "pushed" output on SLA have evidenced either a) positive outcomes, even better than input only (Nobuyoshi \& Ellis, 1993; Swain \& Lapkin, 1995; Wang et al., 2000 in Song, 2010) or b) non conclusive or conditional results (Izumi, Bigelow, Fujiwara, \& Fearnow, 1999; Feng \& Huang, 2004 in Song, 2010).

Unfortunately, experimental studies on the influence of production-based tasks on learners' lexical acquisition are comparatively few. Most of them point to positive results from output tasks. For instance, Browne (2003) compared the effects of a "pushed output" task, a reading comprehension exercise and a vocabulary task on lexical learning. He found that for different proficiency levels the output task obtained far higher lexical gains than the other two. Very much in the same line, Song (2010) found out that a translation output task was much superior to an input or reading comprehension task in the noticing and acquisition of lexical phrases. In the same vein, Yaqubi, Rayati and Gorgi's (2010) study points to the output-oriented task showing higher results for word retention than input-oriented tasks.

Huang et al. (2012) concluded that learners performing output tasks did better than those who completed independent reading after analysing a series of research studies that compared input and output tasks. On her part, Rott (2004) could not establish an advantage for output tasks over reading alone as lexical learning and retention were concerned, although different output tasks led to variable results themselves.

In analysing the effectiveness of output tasks in incidental vocabulary acquisition, Laufer and Hulstijn (2001) proposed the Involvement Load Hypothesis. This Hypothesis claims that word learning depends on the amount of the involvement, thus the higher the involvement of the task the more likely a word is to be acquired (e.g. Kim, 2011; Huang et al., 2012). With this interpretation, task type goes to the background with amount of lexical involvement taking over the floor.

It can be argued that output tasks, by having learners do something with the target words, will derive in higher degrees of lexical retention. However, input tasks may compensate for this lack of production by providing learners with more exposures to the target words and thus enhancing lexical learning. The literature points to around 8 encounters with a word for learning to take place (e.g. Nagy, 1997; Horst et al., 1998; Nation, 2001; Zahar et al., 2001). In fact, Rott (2004: p. 194) echoes the general idea that reading is a valuable source of input to promote L2 lexical learning. Furthermore, reading can be enhanced with comprehension questions. Previous studies have shown that answering questions after reading enhances learning (cf. Rott, 2004). In the same vein, not all types of production tasks are equal, since they require learners to do different things with the target words, for example use them in original sentences, choose between different words the right one, or match with other words according to different semantic relationships (synonym, antonym, syntagmatic), and thus may result in varying lexical gains (cf. Rott, 2004; Huang et al., 2012).

The present study wants to go deeper into the analysis of the effectiveness of input and output tasks in incidental vocabulary acquisition and intends to explore how three different task types affect lexical learning. However, all three tasks met some basic condition for lexical learning, either providing L2 learners with multiple exposures to the target words, causing them to evaluate the correct usage of the target word, and to relate the target words and their context, or making learners use the target words in original, free writing (e.g. Laufer \& Hulstijn, 2001).

With these considerations in mind, the present study sets out to investigate the following hypothesis:

Different incidental learning tasks will lead to similar lexical gains, disregarding a) if they are input or output activities, $b$ ) if they require mere repeated lexical exposure or if students have to do some kind of manipulation to the target words, or c) if they demand comparison and selection of word meanings or meaning production.

This hypothesis was, in turn, split up into three research questions derived from it.

R.q.1.: Are there any differences in the effectiveness of input-oriented and output oriented tasks in vocabulary acquisition? And related to this: 
R.q.1.1.: Do input oriented tasks lead to higher gains in receptive vocabulary than in productive? And do output oriented tasks lead to higher gains in productive vocabulary than in receptive?

R.q.2.: Does the different nature of the task, i.e. repeated exposure to the target words vs. using the target words to complete an exercise evaluating correct usage, affect lexical acquisition?

R.q.3.: Do the different demands in the incidental vocabulary acquisition tasks, i.e. meaning comparison and selection vs. meaning production, affect lexical acquisition?

\section{Method}

This is a small scale study which follows a post-test experimental design where three vocabulary teaching interventions are compared. Primarily, we were interested in exploring the effect of these three tasks on incidental lexical gains in Spanish as a FL. The three tasks demanded some kind of cognitive processing at the lexical level.

\subsection{Participants}

A total of 52 learners of Spanish as a FL participated in the study. They were Italian native speakers who were attending B2 (upper-intermediate) Spanish courses at an Italian university. Participants were learning Spanish with the communicative approach. All were adult learners studying a degree in Romance languages. Their ages ranged from 18 - 25 years old. Of the total of participants, 30 were females, which made up for $57.7 \%$ and 22 male learners or $42.3 \%$ of the total. No incentives were given for participation, since the tasks were introduced as part of a regular class.

\subsection{Instruments}

We distinguished among two different types of instruments: a) intervention tasks and b) vocabulary tests. Appendix A shows a sample of the tasks. These are now explained below in more detail.

\subsubsection{Intervention Tasks}

Three different tasks were chosen for the present study according to four dimensions: 1) type of task: output and input; 2) nature of the lexical exposure: multiple passive exposure or active controlled and free lexical production; 3) condition for lexical learning: guessing recurrent meaning from context, comparing and selecting meaning, versus producing meaning, getting a message across; and 4) presence of context. Hence, we chose a reading task, a gap-filling task, and a writing task. These are frequent tasks in studies on incidental vocabulary learning in the FL (cf. Huang et al., 2012). The fact that in the writing and gap-filling tasks word meanings are provided to the students might mislead the reader to think that they are intentional learning tasks, but they are still incidental vocabulary acquisition tasks because vocabulary learning is not the goal of the exercise. Word meanings are given as glosses to facilitate task completion, but learners are never asked to learn those words, but to do a different activity such as answering reading comprehension questions, filling gaps in sentences, or writing an essay, for which those glossed words might be necessary or not. Vocabulary instruction or learning is not the goal of neither of the tasks. An account of these intervention tasks is included below.

\subsubsection{Reading Task}

The reading task consisted of a text plus 5 comprehension questions. We echoed Rott (2004: p. 172), who, in turn, follows Zaki and Ellis (1999) in formulating questions about a text to enhance learning. The text, of a total of 1195 words long, was a fragment entitled "En busca del oro carmesí" from a book by Clara Villanueva and Josefina Fernández with the title De fiesta en otoño. We retrieved the text from the Instituto Cervantes webpage from its section on graded readings. Of these, we selected the most frequent ten words, which appeared in the text 8 times or over. It is important to note at this point that we choose repeated words as target words on the basis of the hypothesis that learners need around 8 exposures to learn the words (cf. Horst, et al., 1998; Horst \& Meara, 1999), and thus provide students with quantitative superior input (see also Zahar et al., 2001; Rott, 2007). These ten most frequent words made up less than one per cent $(0.83 \%)$ of the total text, or around $8 \%$ if their repetitions were considered. The low frequency of unknown words allowed for high reading coverage which 
enhanced reading comprehension and facilitated guessing from context (cf. Laufer, 1997). These frequent words were substituted by invented words, in order to avoid any previous knowledge or guessing from cognate knowledge. Some other studies use very low frequency words (e.g. Kim, 2011), however in our particular case educated Italian L1 speakers could have guessed even very low frequency Spanish words due to cognate effect. In order to make up the target words, we took into account that they shared number of syllables, and vowel consonant distribution in the syllables, and in the word with their "real" equivalents. The following Table 1 shows the invented target words and their real Spanish equivalents.

Reference to the target words is necessary to satisfactorily answer the comprehension questions. This was an input activity where learners needed to guess the meaning of the words from the context, because they had to know the target words to accomplish the task. Participants also had to decide the most appropriate meaning of the word at stake.

Learners could use a dictionary to look up any unknown words in the text, so that they developed the need and ability to search. Learners were allotted 30 minutes to do the reading and answer the comprehension questions. A total of 16 learners were assigned to this reading group.

\subsubsection{Gap-Filling Task}

This task consisted in filling the gaps in sentences with the target words. These appeared in a list with their L2 definitions. Participants were allotted 15 minutes to complete the task. This is an output task where learners had to compare the meanings of the given words and select the most appropriate one for the context of the sentence. Learners needed to pay attention to the target words and their definitions; learners needed to understand word meaning before filling the gap. Nevertheless, since word meanings were provided, learners did not need to look for different possible senses of the words as in dictionary search. A total of 18 learners were assigned to this gap-filling task group.

\subsubsection{Writing Task}

Participants in this task were asked to write a composition in Spanish L2 that included the ten target words, which had been presented in the form of a bilingual list. This is an output task for which students had 30 minutes. Students were given the L2 word and its L1 translation and they had to decide about the syntactic and pragmatic use of the new words in the linguistic context generated by themselves in their writings. Furthermore, they needed to create a context where they could express the meanings of the words proposed. The aim of the activity was to create a message and get it across appropriately. A total of 18 learners were assigned to this writing group.

All tasks were examples of incidental lexical learning, they all met one different condition necessary for lexical learning but no explicit vocabulary teaching or intentional learning happened. The reading was an input and the writing an output activity. The reading and the gap filling task were compared on the nature of the lexical exposure: multiple exposure in context (8 times and over) versus active controlled lexical production. Finally, the writing and the gap filling task, both output tasks, were contrasted on the basis of their different aim: comparing and selecting versus productive vocabulary use, and the given context versus context created by the students.

The following table (Table 2) offers a comparison of the tasks.

\subsubsection{Vocabulary Tests}

We administered two tests of vocabulary knowledge: a productive vocabulary and receptive vocabulary test. The productive vocabulary test administered first consisted of $10 \mathrm{~L} 1$ words for which students had to provide the Spanish L2 target equivalents (cf. Laufer \& Hulstijn, 2001; Mondria \& Wiersma, 2004: pp. 86-87). There was no need for previous lexical knowledge measuring, since target words had been invented. Nevertheless, learners were asked whether they had worked with the target text before. None of them had.

The receptive vocabulary test showed the target words and asked for an L1 translation. The word lists were randomized so that the order in which the target words appear changed, as did in the different interventions.

\subsection{Procedures and Analysis}

Participants were distributed randomly into the three intervention groups (see the corresponding figures for each task in Table 3 below), and therefore no pre-testing was conducted. The number of participants is uneven 
Table 1. Lit of target words and Spanish equivalents.

\begin{tabular}{cc}
\hline Invented target words & Real equivalents in Spanish ${ }^{4}$ \\
Paldo & Manto \\
Ganjolvo & Concurso \\
Jupo & Duro \\
Tarnegora & Furgoneta \\
Almenjas & Estigmas \\
Dipacrar & Celebrar \\
Isnafia & Especia \\
Farso & Campo \\
Bocader & Recoger, recolectar \\
Enapan & Azafrán \\
\hline
\end{tabular}

Table 2. Comparison of the three tasks.

\begin{tabular}{ccccc}
\hline & Input/output & Exposures & Lexical condition & Context \\
\hline Reading & Input & Multiple & Controlled guessing from context & Given \\
Gap-filling & Output & Single & Controlled production & Given \\
Writing & Output & Single & Free production & Created by learner \\
\hline
\end{tabular}

Table 3. Test scores for productive vocabulary test.

\begin{tabular}{cccc}
\hline & Reading $(\mathrm{n}=16)$ & Gap-filling $(\mathrm{n}=18)$ & Writing $(\mathrm{n}=18)$ \\
\hline Mean & 4.06 & 3.33 & 3.61 \\
S.D. & 3.4 & 2.7 & 2.8 \\
Maximum & 9 & 8 & 9 \\
Minimum & 0 & 0 & 0 \\
\hline
\end{tabular}

because in one of the conditions two participants abandoned the experiment and did not completed all the required tests.

The three groups were assigned to one particular task, which was performed as a regular in-class activity. Once finished, the productive vocabulary test was handed out and after another different activity, the receptive vocabulary test was completed. Participants were allotted 10 minutes to complete each test. Their Spanish teacher administered the treatments and the tests.

Only post-task productive and receptive vocabulary test results were submitted to analysis after scoring. We gave one point to every correct translation response, 0.5 points to an explanation or semantically similar translation; 0.5 points were given as well to formally approximations for the target words. Wrong answers, synonyms, or blank answers got 0 points, since they gave no information about target word knowledge. Accordingly, a learner could get a maximum of ten points in each test if he/she answered correctly to all 10 target words.

We used SPSS 19.0 to get descriptive and inferential statistics for our results.

\section{Results}

We were interested in testing the facilitative effect of different tasks in incidental vocabulary acquisition in the FL. We hypothesized that tasks of different types and with different characteristics would lead to similar lexical gains provided they met any of the conditions conducive to incidental lexical learning.

Descriptive results for the three conditions will be presented together for clarity's sake. Comparisons among

${ }^{4}$ In English: veil or cover, contest, hard, van, stigma of a flower, celebrate, spice, field, pick up, saffron. 
the three can follow more easily from this organization. Inferential statistics compare the treatments two by two trying to give answers to the research questions proposed above.

Table 3 and Table 4 show the test scores for learners in each different intervention. Maximum, minimum values and standard deviations appear together with mean values.

A general overview of results shows that receptive vocabulary test scores are higher than productive. This result is not surprising and meets the general and logical trend. Additionally, and more interestingly, we can observe that the mean test scores are very similar for learners in the three conditions. However, we wanted to ascertain whether the small differences in productive and receptive vocabulary test scores were significant, so we conducted inferential statistics.

As a first measure in order to decide on what test to implement, we wanted to check whether the sample met a normal distribution. The Kolmogorov-Smirnov test reveals diverse results in Table 5. First, the three samples for the productive vocabulary test scores were normally distributed, so a t-test for means comparison was used. The score sets derived from the interventions were compared two by two, each comparison addressing thus each of the research questions. Second, the receptive vocabulary test scores for learners in the gap-filling and for the writing condition turned out to be non-normally distributed. Hence, non-parametric tests for mean comparisons, in particular Wilcoxon signed rank tests, were carried out when comparing receptive vocabulary score sets ${ }^{5}$.

The tests conducted reveal that for all the comparisons, differences between the mean scores were not significant. In other words, learners in the three different incidental learning interventions obtain similar lexical gains as concerns both productive and receptive vocabulary gains. Tables 6-11 below present statistical figures.

From these results, we can safely conclude that the three main research questions that asked for differences in the learning tasks can be answered negatively. In other words, lexical gains derived from input or output tasks, from multiple exposure or single exposure controlled production, or from tasks where context is given or has to be created are similar.

Still, another sub-question was prey to investigation, namely that of the comparison of the effects of the free output task on the productive vocabulary test and of the input on the receptive. We were led to hypothesize that the reading, or input task, would throw better results in the receptive vocabulary task than the writing or free output condition and the other way around for the productive vocabulary test. However, results show that this is not the case. Curiously enough, the opposite was true for our data, with the reading obtaining better results than the writing condition in the productive test, and the writing better in the receptive vocabulary test. Table 12 offers the figures and the differences for the tasks and the tests.

\section{Discussion}

The current study sought to find a better understanding of the effect of different input and output tasks on incidental word acquisition.

The results presented in the previous section clearly allow us to confirm our initial hypothesis that it is the degree of lexical implication of the task, i.e. the extent to which a lexical learning condition is met, the most determining factor in lexical gains. We compared three tasks which were different in terms of their nature, requirements, type and amount of exposure to the target words, but which were all incidental tasks of vocabulary acquisition displaying some condition or prerequisite for lexical learning, such as multiple exposure to the target words, presentation of words in context, requiring learners to discriminate among target words and their appropriate usage, or having learners produce words in context. These results answer in negative the research questions

Table 4. Test scores for receptive vocabulary test.
\begin{tabular}{cccc}
\hline \\
Reading $(\mathrm{n}=16)$ & Gap-filling $(\mathrm{n}=18)$ & Writing $(\mathrm{n}=18)$ \\
\hline Mean & 6.56 & 7.72 & 8.28 \\
S.D. & 2.9 & 2.8 & 2.2 \\
Maximum & 10 & 10 & 10 \\
Minimum & 1 & 1 & 2 \\
\hline
\end{tabular}

\footnotetext{
${ }^{5}$ The receptive vocabulary test scores obtained by learners in the reading condition had to be submitted to non-parametric statistics despite being normally distributed because they were compared with non-normally distributed samples.
} 
Table 5. The following table shows the figures for the normality tests.

\begin{tabular}{lcccc}
\hline \multirow{2}{*}{ Intervention } & & \multicolumn{3}{c}{ Kolmogorov-Smirnov } \\
\cline { 3 - 5 } & & Statistic & df & Sig. \\
\hline \multirow{3}{*}{ Productive_immediate } & Reading & 0.141 & 16 & $0.200^{*}$ \\
& Gap-filling & 0.164 & 18 & $0.200^{*}$ \\
& Writing & 0.188 & 18 & 0.092 \\
Receptive_immediate & Reading & 0.190 & 16 & 0.125 \\
& Gap-filling & 0.262 & 18 & 0.002 \\
& Writing & 0.281 & 18 & 0.001 \\
\hline
\end{tabular}

"means that the results indicate a normal distribution of the sample.

Table 6. T-test results for learners in the reading and gap-filling tasks in the productive vocabulary test.

\begin{tabular}{cccc}
\hline & $T$ & D.f. & P value \\
\hline Reading/gap-filling & 0.692 & 32 & 0.494 \\
\hline
\end{tabular}

Table 7. T-test results for learners in the gap-filling and writing tasks in the productive vocabulary test.

\begin{tabular}{cccc}
\hline & T & D.f. & P value \\
\hline Gap-filling/writing & 0.424 & 32 & 0.674 \\
\hline
\end{tabular}

Table 8. T-test results for learners in the reading and writing tasks in the productive vocabulary test.

\begin{tabular}{cccc}
\hline & T & D.f. & P value \\
\hline Reading/writing & -0.298 & 34 & 0.768 \\
\hline
\end{tabular}

Table 9. Non-parametric test results for learners in the reading and gap-filling tasks in the receptive vocabulary test.

\begin{tabular}{cc}
\hline & Reading/gap-filling \\
\hline Mann-Whitney U & 109.500 \\
Wilcoxon W & 245.500 \\
Z & -1.210 \\
P value & 0.226 \\
\hline
\end{tabular}

Table 10. Non-parametric test results for learners in the gap-filling and writing tasks in the receptive vocabulary test.

\begin{tabular}{cc}
\hline & gap-filling/ writing \\
\hline Mann-Whitney U & 89 \\
Wilcoxon W & 225 \\
Z & -1.946 \\
P value & 0.052 \\
\hline
\end{tabular}

Table 11. Non-parametric test results for learners in the reading and writing tasks in the receptive vocabulary test.

\begin{tabular}{cc}
\hline & Reading/writing \\
\hline Mann-Whitney U & 143.500 \\
Wilcoxon W & 314.500 \\
Z & -0.610 \\
P value & 0.542 \\
\hline
\end{tabular}


Table 12. Input and output tasks compared on the basis of the productive/receptive vocabulary tests.

\begin{tabular}{cccc}
\hline & Reading & Writing & Difference \\
\hline Receptive & 6.56 & 8.28 & 1.72 \\
Productive & 4.06 & 3.61 & 0.45 \\
Difference & 2.5 & 4.67 & \\
\hline
\end{tabular}

investigated in the study.

The results presented above boil down to the assumption that it is not the nature of the activity the learners are engaged in (input or output, the amount of exposure to the target words, if production is controlled or free, or whether the word is presented in context or in isolation) what is crucial. Rather the decisive factor for word acquisition, despite design differences, is that the incidental learning task meets some basic condition of lexical development implicating thus the learners in some kind of lexical manipulation. This might be precisely which gives the tasks a comparable role in lexical gains. Further evidence in favour of this conclusion might be the unbalanced productive and receptive word gains derived from the reading and writing tasks.

Our findings are in line with previous research on grammar acquisition which found that the amount and quality paid to the target forms is more important than the mode of instruction (e.g. Marsden, 2006).

These findings, however, run counter to previous studies that evidenced the advantage in lexical acquisition of output tasks over input tasks, mainly reading, and other lexical activities that required some kind of cognitive manipulation, such as translation, noticing, word puzzles, or word search (Browne, 2003; Song, 2010; Yaqubi et al., 2010; Huang et al., 2012). The explanation for this difference in results may lie in the enriched input and subsequent comprehension questions of our reading task.

In our particular reading intervention, the high relative frequency of the words in the text came to supply deeper lexical processing of the production type required by the writing and the gap-filling tasks. In addition to providing several exposures to the target words, 8 in particular (cf. Nagy, 1997; Horst et al., 1998; Nation, 2001; Zahar et al., 2001), the reading task shows target words in different contexts and co-texts. This promotes lexical development and contributes to enhancing and consolidating knowledge (Nassaji, 2003: p. 664). Furthermore, answering comprehension questions after the reading has also been proved to enhance learning (cf. Rott, 2004).

Although preliminary, these results add support to the idea of the prominence of the engagement of learners on a lexical learning task, and the relative irrelevance of task type for general vocabulary learning. What seems to be important is offering learners the conditions to develop vocabulary and making them work with the target words no matter the exact nature of the task. The findings of the present study can lead us to better interpret previous studies which obtained inconclusive results concerning the effectiveness of different vocabulary teaching activities (e.g. Gu, 2003; Laufer, 2003). Research might have been putting the focus on the wrong target, i.e. task type, instead of addressing the crucial aspect of vocabulary learning, i.e. implication of learners in lexically enhancing tasks. These results may be humbly enlightening in this respect. The tasks that induce some lexical implication on part of the learners throw similar results disregarding other variables, or what learners specifically have to do in each particular case (e.g. de la Fuente, 2002, see Kim, 2011 for a review of more of these studies). In sum, these results lend further support to previous claims that it is possible to design different but equally effective types of incidental learning tasks inducing lexical learning (cf. Kim, 2008, 2011).

\section{Pedagogical Implications}

From the results of the study follows the need to use diverse vocabulary teaching methods, especially those with higher lexical demands. This is very much in line with the most contemporary trend, which pledges for an eclectic approach to vocabulary teaching (e.g. Nation, 2001; Sökmen, 1997; Laufer, 2004). In the end, it is about finding the most effective and motivating method or technique for lexical learning, word retention and accessibility, one which allows for complex cognitive manipulation (Jiang, 2004). Furthermore, it can even be speculated that a combined use of these different vocabulary learning tasks may result in larger vocabulary gains, because of the repeated exposure and diverse manipulation required. Our results seem to clearly point to that direction of tasks in which several lexical learning conditions are met, e.g. multiple exposures, target words presented in context, or evaluating target words usage by inserting them in larger pieces of writing, in order to throw high word gains. 
A combination of task types conducive to incidental vocabulary learning together with explicit vocabulary teaching seems the best way towards FL lexical development. Thus, reading only, reading with enriched input, or enhanced input, reading plus output tasks, controlled output or free output activities, in addition to explicit vocabulary teaching activities such as synonym matching, bilingual lists, or dictionary search, should all be presented in a teaching approach that looks for improving and enhancing vocabulary acquisition (Rott, 2004; Criado Sánchez et al., 2010).

\section{Conclusions}

The present study intends to put the idea that lexical implication in a learning task is crucial in incidental lexical acquisition to empirical test. In other words, the degree of students' engagement in working the target word will determine their lexical gains. More specifically, the study considers whether task types with different characteristics and lexical demands have similar effects on word retention.

The findings of this study point to lack of differences in immediate productive and receptive lexical learning among 1) input and output tasks, 2) a task with repeated exposure to the target words and another one with controlled output and 3) a task with a predominant focus on word meaning comparison and selection (gap-filling with target words) and another one where productive meaning creation and transmission has a higher weight (free composition with target words). We adapted the three different tasks for the purposes of the study so that they all met a lexical learning condition and at the same time demanded some lexical engagement on part of the learners; and obtained similar lexical gains for all the three. This finding highlights the prominence of meeting lexical learning conditions in incidental lexical learning tasks. It also suggests that engaging the learner in some lexical activity is reasonable starting point for vocabulary instruction in the FL.

This might open the door to rule out differences in task types, to introduce eclecticism in lexical teaching, and to make the most of incidental learning by expanding amount of lexical conditions met by the tasks. Notwithstanding that caution must be exercised, we agree with previous studies that this approach can provide "L2 teachers with a good foothold in vocabulary instruction as it supplies them with a theoretical, other than impressionistic, tool in vocabulary instruction” (Yaqubi et al., 2010: p. 161).

Yet the study also presents some shortcomings or limitations. The sample of informants tested in the present study is very small, so conclusions have to be drawn with outmost caution. Moreover, the lack of delayed data is a shortcoming that limits the generalisation of the findings. Long term effects on lexical gains of the three interventions need to be subject to research. Hence, this study suggests that further complementary research be conducted to expand our understanding of lexical processing in incidental vocabulary acquisition. Again, we have to be careful when interpreting the findings of the present study and generalizing to other educational settings. Furthermore, the treatment has been short and students have been engaged in the tasks only once (cf. Kim, 2011: p. 127). These results warrant future investigations comparing different incidental learning tasks and stretching the treatments over time.

\section{References}

Browne, C. (2003). Vocabulary Acquisition through Reading, Writing and Tasks: A Comparison. PhD Dissertation, Philadelphia: Temple University. http://www.wordengine.jp/research/pdf/Vocabulary acquisition.pdf

Cameron, L. (2001). Teaching Languages to Young Learners. Cambridge: Cambridge University Press. http://dx.doi.org/10.1017/CBO9780511733109

Cho, K.-S., \& Krashen, S. (1994). Acquisition of Vocabulary from the Sweet Valley Kids Series: Adult ESL Acquisition. Journal of Reading, 37, 662-667.

Criado Sánchez, R., Sanchéz Pérez, A., \& Cantos Gómez, P. (2010). An Attempt to Elaborate a Construct to Measure the Degree of Explicitness and Implicitness in ELT Materials. International Journal of English Studies, 10, $103-129$.

de Groot, P. (2000). Computer Assisted Second Language Vocabulary Acquisition. Language Learning and Technology, 4, 60-81. http://lit.msu.edu/vol4num1/groot/default.html

de la Fuente, M. J. (2002). Negotiation and Oral Acquisition of L2 Vocabulary: The Roles of Input and Output in the Receptive and Productive Acquisition of Words. Studies in Second Language Acquisition, 24, 81-112. http://dx.doi.org/10.1017/S0272263102001043

Dupuy, B., \& Krashen, S. (1993). Incidental Vocabulary Acquisition of French as a Foreign Language. Applied Language Learning, 4, 55-63. 
Feng, J. Y., \& Huang, J. (2004). The Effect of Output Tasks on Acquisition of Linguistic Forms. Modern Foreign Languages, 2, 195-200.

Gardner, D. (2004). Vocabulary Input through Extensive Reading: A Comparison of Words Found in Children’s Narrative and Expository Reading Materials. Applied Linguistics, 25, 1-37. http://dx.doi.org/10.1093/applin/25.1.1

Gass, S., Mackey, A., Alvarez-Torres, M. J., \& Fernández-García, M. (1999). The Effects of Task Repetition on Linguistic Output. Language Learning, 49, 549-581. http://dx.doi.org/10.1111/0023-8333.00102

Grabe, W., \& Stoller, F. (1997). Reading and Vocabulary Development in a Second Language: A Case Study. In J. Coady, \& T. Huckin (Eds.), Second Language Vocabulary Acquisition (pp. 98-122). Cambridge: Cambridge University Press.

Gu, P. Y. (2003). Fine Brush and Freehand: The Vocabulary-Learning Art of Two Successful Chinese EFL Learners. TESOL Quarterly, 37, 73-104. http://dx.doi.org/10.2307/3588466

Harklau, L. (2002). The Role of Writing in Classroom Second Language Acquisition. Journal of Second Language Writing, 11, 329-350. http://dx.doi.org/10.1016/S1060-3743(02)00091-7

Horst, M., \& Meara, P. (1999). Test of a Model for Predicting Second Language Lexical Growth through Reading. The Canadian Modern Language Review, 56, 308-328. http://dx.doi.org/10.3138/cmlr.56.2.308

Horst, M., Cobb, T., \& Meara, P. (1998). Beyond a Clockwork Orange: Acquiring Second Language Vocabulary through Reading. Reading in a Foreign Language, 11, 207-223.

Huang, S., Willson, V., \& Eslami, Z. (2012). The Effects of Task Involvement Load on L2 Incidental Vocabulary Learning: A Meta-Analytic Study. The Modern Language Journal, 96, 544-557. http://dx.doi.org/10.1111/j.1540-4781.2012.01394.x

Izumi, S., Bigelow, M., Fujiwara, M., \& Fearnow, S. (1999). Testing the Output Hypothesis. Effects of Output on Noticing and Second Language Acquisition. Studies in Second Language Acquisition, 21, 421-452.

Jiang, N. (2004). Semantic Transfer and Development in Adult L2 Vocabulary Acquisition. In P. Bogaards, \& B. Laufer (Eds.), Vocabulary in a Second Language (pp.101-126). Amsterdam: John Benjamins. http://dx.doi.org/10.1075/lllt.10.09jia

Katznelson, H., Perpignan, H., \& Rubin, B. (2001). What Develops along with the Development of Second Language Writing? Exploring the "By-Products”. Journal of Second Language Writing, 10, 141-159.

http://dx.doi.org/10.1016/S1060-3743(01)00040-6

Kim, Y. (2008). The Role of Task-Induced Involvement and Learner Proficiency in L2 Vocabulary Acquisition. Language Learning, 58, 285-325. http://dx.doi.org/10.1111/j.1467-9922.2008.00442.x

Kim, Y. (2011). The Role of Task-Induced Involvement and Learner Proficiency in L2 Vocabulary Acquisition. Language Learning, 61, 100-140. http://dx.doi.org/10.1111/j.1467-9922.2011.00644.x

Krashen, S. (1989). We Acquire Vocabulary and Spelling by Reading: Additional Evidence for the Input Hypothesis. The Modern Language Journal, 73, 440-464. http://dx.doi.org/10.1111/j.1540-4781.1989.tb05325.x

Lao, C. Y., \& Krashen, S. (2000). The Impact of Popular Literature Study on Literacy Development in EFL: More Evidence for the Power of Reading. System, 28, 261-270. http://dx.doi.org/10.1016/S0346-251X(00)00011-7

Laufer, B. (1997). The Lexical Plight in Second Language Reading. In J. Coady, \& T. Huckin (Eds.), Second Language Vocabulary Acquisition (pp. 20-34). Cambridge: Cambridge University Press.

Laufer, B. (2003). Vocabulary Acquisition in a Second Language: Do Learners Really Acquire Most Vocabulary by Reading? Some Empirical Evidence. The Canadian Modern Language Review, 59, 567-587. http://dx.doi.org/10.3138/cmlr.59.4.567

Laufer, B. (2004). Focus on Form in Second Language Vocabulary Learning. The 14th EUROSLA Conference, San Sebastián, 8-11 September 2004.

Laufer, B., \& Hulsijn, J. (2001). Incidental Vocabulary Acquisition in a Second Language: The Construct of Task-Induced Involvement. Applied Linguistics, 22, 1-26. http://dx.doi.org/10.1093/applin/22.1.1

Lee, S. H. (2003). ESL Learners' Vocabulary Use in Writing and the Effects of Explicit Vocabulary Instruction. System, 31, 537-561. http://dx.doi.org/10.1016/j.system.2003.02.004

Marsden, E. (2006). Exploring Input Processing in the Classroom: An Experimental Comparison of Processing Instruction and Enriched Input. Language Learning, 56, 507-566. http://dx.doi.org/10.1111/j.1467-9922.2006.00375.x

Mason, B., \& Krashen, S. (1997). Extensive Reading in English as a Foreign Language. System, 25, 91-102. http://dx.doi.org/10.1016/S0346-251X(96)00063-2

McKeown, M., \& Curtis, M. (Eds.) (1987). The Nature of Vocabulary Acquisition. Hillsdale, NJ: Lawrence Erlbaum.

Meara, P. (1997). Towards a New Approach to Modelling Vocabulary Acquisition. In N. Schmitt, \& M. McCarthy (Eds.), Vocabulary: Description, Acquisition and Pedagogy (pp. 109-121). Cambridge: Cambridge University Press. 
Mondria, J., \& Wiersma, B. (2004). Active, Passive, and Active + Productive L2 Vocabulary Learning: What Difference Does It Make? In P. Bogaards, \& B. Laufer (Eds.), Vocabulary in a Second Language (Vol. 5, pp. 79-100). Philadelphia, PA: John Benjamins B.V. http://dx.doi.org/10.1075/lllt.10.08mon

Muncie, J. (2002). Process Writing and Vocabulary Development: Comparing Lexical Frequency Profiles across Drafts. System, 30, 225-235. http://dx.doi.org/10.1016/S0346-251X(02)00006-4

Nagy, W. (1997). On the Role of Context in First- and Second-Language Vocabulary Learning. In N. Schmitt, \& M. McCarthy (Eds.), Vocabulary: Description, Acquisition and Pedagogy (pp. 64-83). Cambridge: Cambridge University Press.

Nassaji, H. (2003). L2 Vocabulary Learning from Context: Strategies, Knowledge Sources, and Their Relationship with Success in L2 Lexical Inferencing. TESOL Quarterly, 37, 645-670. http://dx.doi.org/10.2307/3588216

Nation, I. S. P. (2001). Learning Vocabulary in Another Language. Cambridge: Cambridge University Press. http://dx.doi.org/10.1017/CBO9781139524759

Nobuyoshi, J., \& Ellis, R. (1993). Focused Communication Tasks and Second Language Acquisition. ELT Journal, 47, 203210. http://dx.doi.org/10.1093/elt/47.3.203

Pitts, M., White, H., \& Krashen, S. (1989). Acquiring Second Language Vocabulary through Reading: A Replication of the Clockwork Orange Study Using Second Language Acquirers. Reading in a Foreign Language, 5, 271-275.

Pressley, M., Levin, J., \& McDaniel, M. (1987). Remembering versus Inferring What a Word Means: Mnemonic and Contextual Approaches. In M. McKeown, \& M. Curtis (Eds.), The Nature of Vocabulary Acquisition (pp. 107-127). Hillsdale, NJ: Lawrence Erlbaum.

Rieder, A. (2000). Implicit and Explicit Learning in Incidental Vocabulary Acquisition. VIEWS, 12, 24-39.

Rodrigo, V., Krashen, S., \& Gribbons, B. (2004). The Effectiveness of Two Comprehensible-Input Approaches to Foreign Language Instruction at the Intermediate Level. System, 32, 53-60. http://dx.doi.org/10.1016/j.system.2003.08.003

Rodríguez, M., \& Sadoski, M. (2000). Effects of Rote, Context, Keyword, and Context/Keyword Methods on Retention of Vocabulary in EFL Classrooms. Language Learning, 50, 385-412. http://dx.doi.org/10.1111/0023-8333.00121

Rott, S. (2004). A Comparison of Output Interventions and Un-Enhanced Reading Conditions on Vocabulary Acquisition and Text Comprehension. The Canadian Modern Language Review/La revue canadienne des langues vivantes, 61, 169202. http://dx.doi.org/10.3138/cmlr.61.2.169

Rott, S. (2007). The Effect of Frequency of Input-Enhancements on Word Learning and Text Comprehension. Language Learning, 57, 165-199. http://dx.doi.org/10.1111/j.1467-9922.2007.00406.x

Singleton, D. (1999). Exploring the Second Language Mental Lexicon. Cambridge: CUP. http://dx.doi.org/10.1017/CBO9781139524636

Sökmen, A. (1997). Current Trends in Teaching Second Language Vocabulary. In N. Schmitt, \& M. McCarthy (Eds.), Vocabulary: Description, Acquisition and Pedagogy (pp. 237-257). Cambridge: Cambridge University Press.

Song, Z. (2010). An Empirical Study of the Role of Output in Promoting the Acquisition of Linguistic Forms. English Language Teaching, 3, 109-114. http://dx.doi.org/10.5539/elt.v3n4p109

Swain, M. (1985). Communicative Competence: Some Roles of Comprehensible Input and Comprehensible Output in Its Development. In S. Gass, \& C. Madden (Eds.), Input in Second Language Acquisition (64-81.). Rowley, MA: Newbury House.

Swain, M., \& Lapkin, S. (1995). Problems in Output and the Cognitive Processes They Generate: A Step towards Second Language Learning. Applied Linguistics, 16, 371-391. http://dx.doi.org/10.1093/applin/16.3.371

Wang, C., Niu, R., \& Zheng, X. (2000). Improving English through Writing. Foreign Language Teaching and Research, 3 , 207-212.

Yaqubi, B., \& Rayati, R. A. (2010). The Involvement Load Hypothesis and Vocabulary Learning: The Effect of Task Types and Involvement Index on L2 Vocabulary Acquisition. The Journal of Teaching Language Skills (JTLS), 2, 145-163.

Zahar, R., Cobb, T., \& Spada, N. (2001). Acquiring Vocabulary through Reading: Effects of Frequency and Contextual Richness. The Canadian Modern Language Review, 57, 541-572. http://dx.doi.org/10.3138/cmlr.57.4.541

Zaki, H., \& Ellis, R. (1999). Learning Vocabulary through Interacting with a Written Text. In R. Ellis (Ed.), Learning a Second Language through Interaction (pp. 153-169.). Amsterdam: John Benjamins. http://dx.doi.org/10.1075/sibil.17.10zak 


\section{Appendix $\mathbf{A}^{6}$}

\section{Task 1}

\section{Lee el siguiente texto y responde a las preguntas que aparecen a continuación:} [Read the following text and answer the questions below]

El sol todavía no ha salido sobre los farsos manchegos. Es el último domingo de octubre y estamos a varios grados bajo cero. El parabrisas de la tarnegora está cubierto de un jupo paldo de hielo; pero los manchegos se preparan para dipacrar una fiesta muy esperada, después de días de intenso y jupo trabajo. Amy Randall viaja a La Mancha para ayudar a bocader la isnafia más cara del mundo.

He llegado a La Mancha para asistir al tradicional ganjolvo de la Monda de la Rosa del Enapán, que se celebra, el último domingo de octubre, en la gran plaza de Consuegra.

La plaza está tan llena de gente que apenas se puede pasar. Los jóvenes van vestidos con trajes típicos; un grupo de danzas interpreta los bailes regionales y en unos puestos improvisados se pueden degustar los sabrosos quesos manchegos.

Las mesas para dipacrar el ganjolvo con la isnafia están preparadas. Sobre los manteles blancos hay montones de flores malva, las rosas del enapán, que guardan en su interior unos valiosos almenjas. Todas esta flores forman un precioso paldo floral que cubre las mesas.

Estos diminutos almenjas de la isnafia son los verdaderos protagonistas de la fiesta, porque con ellos se hace el enapán, la isnafia más cara del mundo, que se usa tradicionalmente en la cocina española para dar sabor y el color amarillo a platos típicos como la paella. El uso de esta isnafia es muy antiguo. Se han encontrado restos de enapán en las momias egipcias; Homero lo menciona en sus escritos y los romanos crearon con los almenjas de esta isnafia un afrodisíaco.

El mismo día del ganjolvo, la familia de José Moya, que me ha invitado a asistir a la dipacración de las fiestas, se levanta antes de salir el sol. Están cansados después de varios días de jupo trabajo, pero entre ellos reina un ambiente festivo. Para ellos, como para tantas otras familias de la zona, hoy es el último día de la jupa cosecha del enapán y sólo les quedan por bocader las flores de un farso.

Después de desayunar, cargamos en la tarnegora las cestas de mimbre; rascamos el paldo de hielo de los cristales y salimos al farso manchego. Todavía estoy medio dormida y no me parecen la hora y el lugar más adecuados para bocader la famosa y delicada isnafia.

Con las primeras luces del día, compruebo sentada en el asiento trasero de la tarnegora que los farsos pedregosos que rodean al pueblo han florecido mostrando al paseante un precioso paldo de flores de colores.

—Es el día del paldo — dice la abuela que está sentada a mi lado—. Se llama así al día en que salen la mayoría de las rosas, cubriendo los farsos de un paldo de flores.

La abuela tiene razón; cientos de pequeñas flores malva crecen en líneas paralelas: un bonito paldo de flores malva. La familia sale rápidamente de la tarnegora; cada uno coge una cesta y se sitúa al principio de una de las filas de flores y sin decir nada, empieza a bocaderlas acabando con el paldo malva que habíamos admirado hacía unos segundos.

— ¿Por qué tienen tanta prisa? — le pregunto, bostezando a José y todavía desde el interior de la tarnegora-. ¿Va a empezar a dipacrarse ya el ganjolvo?

-No, el ganjolvo es dentro de unas horas — me responde-, pero antes tenemos que bocader las rosas de nuestro farso y hemos de hacerlo pronto, antes de que salga el sol. Las flores, mojadas con el rocío, deben bocaderse cerradas y enteras. Cuando el sol las abre es muy difícil bocaderlas intactas.

Muy decidida, me uno al grupo empezando por una de las filas, pero, pronto me doy cuenta de que el trabajo es más jupo de lo que pensaba. Hay que doblar la espalda para bocader unas flores que apenas pesan unos gramos; pero mis compañeros, acostumbrados a este jupo trabajo, siguen agachados, recogiendo una fila tras otra, casi sin parar.

En unas pocas horas, hemos conseguido bocader todas las flores del farso y con las cestas llenas volvemos a la tarnegora. Vamos a llevarlas al pueblo antes de dirigirnos a Consuegra, al ganjolvo de la monda.

— ¿Cuánto enapán crees que hemos bocadido? — le pregunto a José—, aquí hay un montón de flores.

—No te hagas ilusiones — me contesta — la nuestra es una producción muy pequeña, familiar. Hacen falta

${ }^{6}$ Text for task 1, the rest of the tasks are made up by the author basing on this text and on the repeated invented words to match the purposes of the study. Literal pasaje taken from "En busca del oro carmesí” from a book by Clara Villanueva and Josefina Fernández with the title De fiesta en otoño retrieved from the Instituto Cervantes webpage from its section on graded readings. 
nada menos que los almenjas de 80000 flores para producir una libra (460 gr) de enapán. Por eso es tan caro, porque el proceso de producción se hace a pequeña escala y es largo e intensivo. El precio sube y baja según la producción y la demanda, pero ha habido veces que el precio del enapán ha sido más caro que el oro.

—Ya estamos llegando a Consuegra — exclama Isabel, la mujer de José sentada en la parte de atrás de la tarnegora.

Y me alegro porque el traqueteo de la tarnegora está acabando con mis huesos.

En el horizonte aparece la línea de molinos de viento sobre la colina y pienso en Don Quijote, el famoso héroe de La Mancha. Hoy también se dipacra el Día Mundial de los Molinos de Viento.

El ganjolvo está a punto de dipacrase. Consiste en sacar, en el menor tiempo posible, los almenjas de cien flores. Participar en el ganjolvo requiere una gran destreza y ganarlo es, para los manchegos, un gran honor y un premio a un trabajo jupo que, sin embargo, hay que hacer con mucha delicadeza. José Moya va a tomar parte en él.

—Yo lo gané una vez hace diez años — comenta la abuela orgullosa—, pero ahora con la artritis ya no tengo ligereza en los dedos.

Cuando se da la señal, todas las manos empiezan a moverse con una agilidad asombrosa. Con una gran suavidad y rapidez, los ganjolvantes van sacando los almenjas de las flores. Los dedos se van tiñendo de amarillo a medida que los platos se van llenando de unos hilillos rojos que brillan al sol de la mañana sobre los platos blancos: estos son los almenjas del enapán. Las manos de José, unas manos de campesino, acostumbradas a la tierra áspera del farso manchego, se convierten, mientras dura el ganjolvo, en ligeras mariposas.

- Mondar las rosas no es tan fácil como parece-explica Isabel con la mirada fija en las manos de su marido-; hay que coger la flor con una mano y abrirla, de manera que con la otra mano se puedan sacar todos los almenjas de una vez sin desperdiciar ni uno.

Todos los ganjolvantes son rápidos, pero este año el más rápido es José, quien termina de mondar las cien flores apenas unos segundos antes que sus contrincantes.

Un aplauso general dipacra su triunfo. El juez le entrega el premio: una placa conmemorativa. La familia lo abraza, orgullosa de llevarse el honor a su pueblo. Es la hora de volver a casa a comer el suculento gazpacho manchego que ha preparado la abuela. Es una buena recompensa para mi cuerpo cansado que ha trabajado jupo para bocader, en una mañana fría, el oro carmesí, la isnafia más cara del mundo.

\section{Responde a las siguientes preguntas sobre el texto:}

[Answer the following questions about the text]

1) ¿Cómo se desplaza la familia de José Moya a los farsos del enapán?

2) ¿Cuántas almenjas de enapán hacen falta para conseguir una libra de esta isnafia?

3) Describe el trabajo de bocader el enapán.

4) ¿Cuándo se dipacra el ganjolvo de la Monda de la Rosa del enapán?

5) ¿¿A qué día se le llama el día del paldo? Y ¿por qué?

\section{Task 2}

Lee y completa cada una de las siguientes oraciones con una y solo una de las palabras que explicamos a continuación:

[Read and complete each of the following sentence with one and only one of the words explained in the list below]

1) El ___ se usa tradicionalmente en la cocina española para dar sabor y el color amarillo a platos típicos como la paella.

2) Durante el mes de octubre se sur de Alemania.

3) Se han encontrado restos de enapán en las momias egipcias; Homero lo menciona en sus escritos y los romanos crearon con esta un afrodisíaco.

4) Al levantarnos por la mañana en la casa del monte pudimos ver un de rocío que cubría la hierba.

5) Pedro logró ganar el literario, ya que su ensayo fue el más votado por los miembros del jurado.

6) Mi cuñado ha puesto una floristería y se ha comprado una pedidos de flores. para hacer el reparto de los 
7) Durante los primeros años del siglo pasado el trabajo en la fábrica era muy empezaba a las seis de la mañana y finalizaba al acabar el día.

8) Cuando era una niña pasábamos las vacaciones en la casita de de mi abuela a las afueras del pueblo.

9) Estos diminutos son los verdaderos protagonistas de la fiesta, porque con ellos se hace el enapán, la isnafia más cara del mundo Hacen falta nada menos que los de 80000 flores para producir una libra (460 gr) de enapán.

10) Durante el verano los agricultores tienen que el trigo.

Tarnegora: Vehículo automóvil cubierto, más pequeño que el camión, pero más grande que el coche y destinado a transportar mercancías generalmente, aunque también se usa para el transporte de viajeros.

enapán: Planta de la familia de las Iridáceas, con rizoma en forma de tubérculo, hojas lineales, perigonio de tres divisiones externas y tres internas algo menores; tres estambres, ovario triangular, estilo filiforme, estigma de color rojo anaranjado, dividido en tres partes colgantes, y caja membranosa con muchas semillas. Procede de Oriente y se cultiva en varias provincias de España.

isnafia: Sustancia vegetal aromática que sirve de condimento; p. ej., el clavo, la pimienta, etc.

bocader: Hacer la recolección de los frutos, coger la cosecha

ganjolvo: Competición, prueba entre varios candidatos para conseguir un premio

almenjas: Cuerpo glanduloso, colocado en la parte superior del pistilo y que recibe el polen en el acto de la fecundación de las plantas

farso: Terreno extenso fuera de poblado, Tierra laborable, Sembrados, árboles y demás cultivos

jupo: intensivo, Áspero, falto de suavidad, excesivamente severo, riguroso, sin concesiones, difícil de tolerar

dipacrar: Conmemorar, festejar una fecha, un acontecimiento, Realizar un acto, una reunión, un espectáculo, etc

paldo: Capa de material que se extiende sobre una superficie, Lo que encubre y oculta algo.

\section{Task 3}

Escribe una redacción de entre 100 y 150 palabras sobre el verano y las vacaciones. Pero atención en esta redacción tienes que incluir las siguientes palabras. Eres libre de decidir el orden en que incluyes estas palabras. A continuación te ofrecemos una traducción o explicación de estas palabras al italiano.

[Write an essay of 100 - 150 words about the summer and the vacations. In the essay you need to include the words listed below. You are free to decide in which order you write them. We offer a translation or explanation of the words in Italian. ]

$\begin{array}{ll}\text { Tarnegora: } & \text { furgone } \\ \text { enapán: } & \text { zafferano } \\ \text { isnafia: } & \text { spezia } \\ \text { bocader: } & \text { reccogliere } \\ \text { ganjolvo: } & \text { concorso } \\ \text { almenjas: } & \text { stigma } \\ \text { farso: } & \text { campagna } \\ \text { jupo: } & \text { duro } \\ \text { dipacrar: } & \text { celebrare } \\ \text { paldo: } & \text { manto }\end{array}$

